U.S. Department of the Interior

U.S. Geological Survey

Streamflow Information for the Nation

Since 1887, the U.S. Geological Survey (USGS) has operated a streamflow-gaging program to collect information about the Nation's water resources. Under this program, the USGS collects the streamflow data needed by Federal, State, and local agencies for planning and operating water-resources projects and regulatory programs.

Over time, the USGS streamflowgaging network (fig. 1) has changed as new needs for streamflow data have emerged and new technologies for data collection, analysis, and dissemination have evolved. In recent years, the USGS has focused on adapting new communications technologies to serve water-resource managers better, developing more efficient datacollection technologies, and expanding partnerships with other Federal, State, and local agencies.

\section{Real-Time Service}

The most profound change in the USGS streamflow-gaging program in

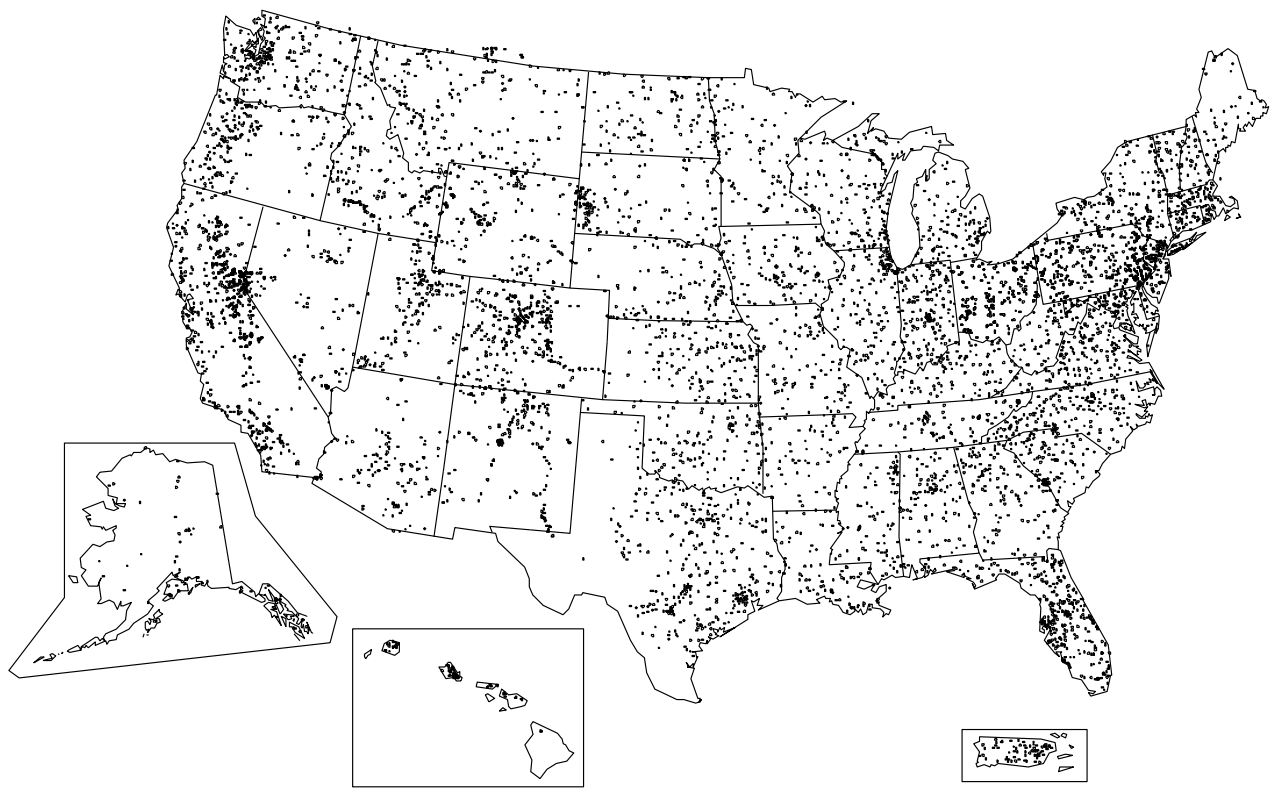

Figure 1. Locations of USGS streamflow-gaging stations. recent years has been the development and widespread use of real-time streamflow data. As the expansion of water-development projects has slowed, the emphasis has shifted to developing management strategies that make optimum use of the Nation's existing water-resources infrastructure. Developing optimal management strategies, however, requires more information in greater detail and in more constrained timeframes than was needed in the past. Through its streamflow-gaging program, the USGS provides data that are critical to the most effective management of the country's vital water resources.

Throughout the country, USGS stations equipped with real-time telemetry are integral components of reservoir operations and river-forecast and flood-warning systems. About 4,200 stations, which total 60 percent of the USGS network, are equipped with automated Data Collection Platforms (DCP's) that use satellite radio transmitters to broadcast streamstage data 24 hours a day directly to major cooperators, such as the National Weather Service (NWS), the U.S. Army
Corps of Engineers, and the Bureau of Reclamation. These and other Federal, State, and local agencies use the riverstage data to forecast river conditions, to issue flood warnings and riverconditions statements, and to plan reservoir releases or water withdrawals. So important are telemetered data to the missions of these agencies that the number of stations equipped with DCP's is steadily being increased (fig. $2 A$ ), even as the overall streamflowgaging network is being reduced (fig. $2 B)$.

Although some agencies are able to operate by using only real-time riverstage data, other users require real-time river-discharge data. Providing discharge data is more difficult than providing stage data because the stage data must be processed through complex and shifting stage/discharge relations to yield meaningful results. Tracking the changes in the stage/ discharge relations and maintaining the accuracy of the relations requires human measurement and interpretation. Consequently, direct broadcast of the discharge data by data-collection instruments at field installations is not currently possible. Instead, near-realtime river-discharge data are provided to major users through modem communications with USGS computers.

To facilitate the dissemination and use of discharge data, the USGS began to provide real-time discharge data to government agencies and the general public through the World-Wide Web (WWW) in 1995. In 1996, hourly streamflow data for more than 2,600 sites were provided through the WWW. Use of the USGS WWW data system has grown rapidly. In September 1996, more than 48,000 hydrographs of realtime discharge data were provided to users throughout the country. During February 1996, more than 11,900 hydrographs of real-time data (fig. 3) on the floods of Washington and Oregon were served to more than 4,800 

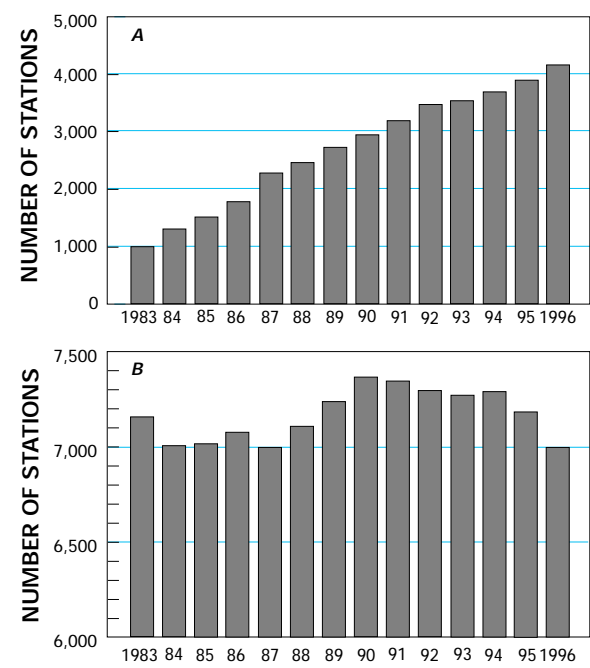

Figure 2. Streamflow-gaging stations. A,With satellite Data Collection Platforms; B, Total number, by year.

non-USGS users who needed to monitor flooded streams. Federal, State, and local agencies used the USGS data to help manage releases from flood-control reservoirs and to assess flood conditions. The widespread use of the streamflow data led to special recognition of the USGS by the U.S. Department of the Interior. In making the special presentation, Assistant Secretary of the Interior for Water and Science, Patricia Beneke, said:

In the Willamette Valley alone, the outstanding partnership between the USGS and other Federal and State agencies, and based on USGS data, saved an estimated 2.7 billion dollars of flood damage in February, as well as the lives of many Oregonians. The work done by the USGS to make streamflow information immediately available to citizens and public safety officials is an excellent example of how this science agency has become increasingly responsive to society's needs.

Although use of the WWW data system has been very successful, it has not been without some setbacks. Datadelivery interruptions are rare, but unusual circumstances have curtailed service in some cases. Widespread telephone and power failures following Hurricane Fran in North Carolina, for example, disrupted operation of the North Carolina USGS computer system, and WWW users were temporarily unable to monitor severe flooding in the State. In response, the river-stage data were rerouted to other remote networks and made available to WWW users. The USGS is working to improve network facilities and backup capabilities.

In addition to near-real-time data, the USGS also provides historical daily streamflow data on the WWW. Daily data for more than 19,000 locations are available. Since release of the data on the WWW in May 1995, use of the historical streamflow data base has grown to about 5,000 users each month. The on-line availability of the USGS data enables users to perform more easily hydraulic and hydrologic analyses that are essential to the planning, design, and operation of water-resources projects. At the same time, serving the data through the WWW has greatly reduced the number of data requests that the USGS previously processed manually.

\section{Real-time streamflow data can be accessed at: http://www.usgs.gov}

\section{New Technology}

The riverine environment is harsh and ever-changing, and few forces of nature match the raw power and persistence of flowing streams. These factors complicate the collection of reliable and accurate streamflow data and underscore the many obstacles faced by the USGS as it seeks to reduce the cost of the streamflow-gaging program.

In recent years, the USGS has employed advanced technologies to improve the reliability of stream-gage instrumentation, to reduce the time required for field measurements, and to extend the range and scope of the datacollection network. Streamflow records are not based on direct measurement of river discharge, but on records of river stage that are converted into discharge by use of stage/discharge relations. River-stage data are collected by automated sensing, recording, and processing equipment that require frequent service, calibration, and adjustment. Usually, these instruments are operated at remote locations and are powered by batteries.

The USGS electronic data recorders operate with less power consumption than the electromechanical recorders that were used previously. In addition, the USGS has installed solar

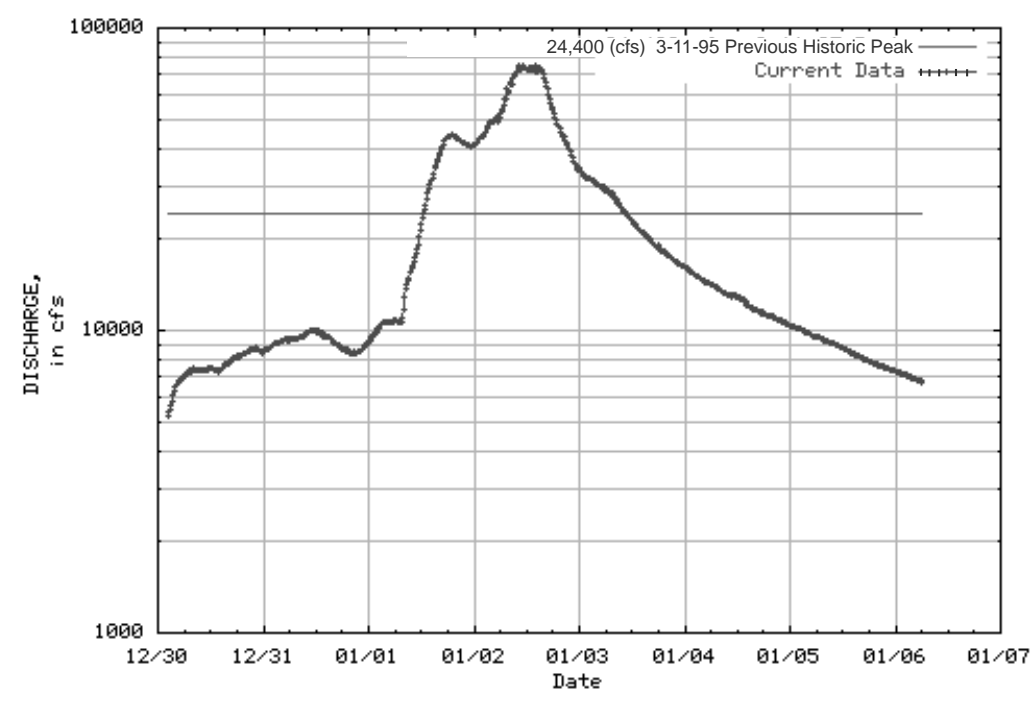

Figure 3. Streamflow hydrograph for Cosumnes River at Michigan Bar, Calif., shows the flood of January 1997; cfs, cubic feet per second. 
cells at most sites to recharge instrument batteries. By reducing power demands and recharging battery systems daily, the USGS has extended the unattended operation of most streamflow-gaging stations and reduced the frequency of service visits. Also, the new recorders are easily equipped with computer modems, cellular telephones, or satellite radio transmitters that improve the delivery and processing of the data.

Stage/discharge relations are developed by direct measurement of river depths, widths, and flow velocities to compute discharge through a range of stages. Initial development of stage/discharge relations typically requires more than 20 separate discharge measurements. Because stage/discharge relations undergo nearly continuous change as the stream adapts to varying flow and channel conditions, additional discharge measurements are needed at frequent intervals. Making these measurements and maintaining the accuracy of stage/discharge relations are significant program expenses. Most measurements of discharge rely on a "tried-and-true" instrument that has been in use since 1885 - the Price current meter. Significant advances in acoustic Doppler technologies, however, have begun to alter USGS dischargemeasurement techniques.

The Acoustic Doppler Current Profiler (ADCP) measures the velocity of water by bouncing sound waves off of water-borne sediments and debris to produce vastly more detailed measurements of the flow velocities and river cross-sections. These measurements are made in a fraction of the time required for the standard current meter. Because of their speed, ADCP's have made possible the stream gaging of some waters that otherwise could not be readily monitored. Studies of hydraulic circulation in large estuaries and harbors and the tidal flux of water and chemical constitutents are greatly facilitated by using an ADCP. Because of the physics of acoustical measurements, however, the use of ADCP's is currently restricted to deep streams with well-defined beds and banks. The total number of these streams is a small fraction of those now gaged by the USGS. The USGS is working with private sector vendors to improve the technology and, thereby, to increase the applicability of ADCP's to smaller streams.

\section{Reduced Network}

The USGS streamflow-gaging network has undergone some significant reductions in recent years. A slow decline in the number of stations that began in 1990 has continued through 1996. As of 1996, the 7,000 stations reflect a reduction of 185 stations from the total in 1995 and 363 stations from the total in 1990.

The stations lost from the network were not distributed uniformly across the country and were generally those that were funded primarily from direct USGS congressional appropriations. That number of stations fell from 550 stations in 1995 to 492 stations in 1996. The most significant reductions occurred in the index-station networks used by the USGS to monitor and document long-term changes and trends in water availability and quality.

Sixty-three stations funded by the Federal-State Cooperative Program were lost from the network. (Under the Cooperative Program, the USGS provides up to 50 percent of the funds required to operate a station, and the State or local agency provides the remainder.) In 1996, 4,035 stations were funded under the Cooperative Program. The number of stations funded by other Federal agencies was unchanged (1,922 stations).

The USGS streamflow-gaging network is an aggregation of networks and individual streamflow stations that have been established for various purposes. Often, however, the data are used for purposes other than those for which the station was operated. As the USGS network has become more focused on direct operational or resource-allocation issues, portions of the network that once addressed broader needs have been reduced. For example, in 1988, 1,098 USGS stations at which streamflow data were collected for other purposes were found suitable for study of climatic change; however, since 1988, the number of these stations has fallen by almost 10 percent, as cooperators have discontinued funding for stations for which there was less operational need and as funding for Federal index stations has been reduced. Furthermore, the focus on direct cooperator funding has had some detrimental effects on some Federal agencies that have relied on data collected at USGS stations that were funded by others. For example, in 1996, the NWS prepared forecasts of river conditions by using data from 3,970 USGS streamflow-gaging stations that the USGS operated for other cooperators. Since 1980, 359 USGS streamflow-gaging stations that were used by the NWS have been discontinued as other cooperators discontinued funding of these stations.

The U.S. Geological Survey stream-gaging network is vital to the National Weather Service's river forecast and warning program and the goal to reduce flood damages and loss of life. Without the data from this network, this nation would experience increased losses from floods of both life and property. [Elbert W. Friday, Jr., Assistant Administrator for Weather Service, National Weather Service, written commun., January 19, 1995]

\section{Partnerships}

For 101 years, the USGS streamflow-gaging program has featured a strong Cooperative Program in which the USGS collects and publishes streamflow data and the USGS and State or local agencies share the costs. In 1996, the streamflowgaging program remains a strong and vital partnership. More than 700 Federal, State, or local agencies cooperate with the USGS in the 
streamflow-gaging program. These agencies fund, in whole or in part, 93 percent of the stations operated by the USGS.

As a central and comprehensive source of useful streamflow data, the USGS streamflow-gaging program provides an essential service to many agencies and organizations involved in water-resource management. The program promotes standardization of the data-collection process, centralization of the data base for multiple users, and cost-efficient operation. Usually, cooperators fund individual stations to obtain data that meet an agencyspecific project or regulatory need.

The USGS, in its governmental role, integrates multiple funding sources to operate a data network that produces much more than if the network were funded and operated by many separate entities.... The unbiased and consistent manner in which the data are collected is extremely important to activities such as diversion accounting between states and regions, settling multistate water disputes, analysis of long term trends in stream flow, etc. [Russell $L$. Fuhrman, Major General, U.S. Army, Director of Civil Works, written commun., 1996]
Reflecting long-term USGS commitment to partnerships, the single most important source of funding for the USGS network is the Cooperative Program. In 1996, State and local agencies contributed $\$ 30$ million to the streamflow-gaging program, $\$ 8$ million more than the USGS was able to match with 1996 appropriations (fig. 4). The second largest source of funding for the USGS streamflow-gaging program is funds from other Federal agencies. In 1996, other Federal agencies contributed \$25 million to the USGS streamflow-gaging program.

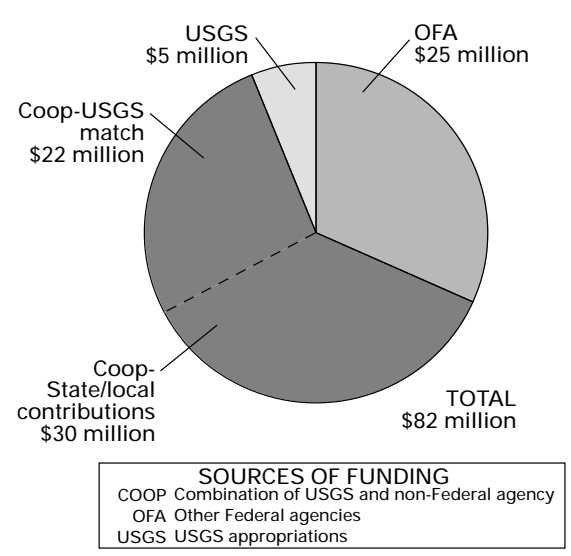

Figure 4. Sources of funds for the U.S. Geological Survey streamflow-gaging program, 1996.

By Robert R. Mason, Jr. and T.H. Yorke U.S. Geological Survey

\section{For more information, contact any of the following:}

\author{
U.S. Geological Survey \\ Office of Surface Water \\ 415 National Center \\ Reston, VA 20192 \\ (703) 648-5977
}

Additional earth science information can be obtained by accessing the USGS Home Page on the WWW at :

\section{http://www.usgs.gov}

For more information on all USGS reports and products (including maps, images, and computerized data), call 1-800-USA-MAPS. 